\title{
Loss, Emotions, and Politics: Mass Graves, Melancholia, and Performance in Santiago Roncagliolo's Abril rojo (2006)
}

Una de las tantas fosas masivas clandestinas en las cuales yacen los cadáveres anónimos de muchas de las víctimas del conflicto entre el estado peruano y el grupo terrorista Sendero Luminoso es representada en la novela Abril rojo (2006) de Santiago Roncagliolo. Este horrendo agujero, además de dar testimonio sobre la violencia del choque armado, sirve como escenario para el performance político de Nélida, la acongojada madre de uno de los muchos desaparecidos del conflicto. Entre gritos, empujones y amenazas, Nélida muestra su interminable tristeza (o melancolía) y establece el infranqueable compromiso que tiene para con su hijo. Mediante estas acciones ella también protesta con singular potencia los abusos y crímenes cometidos durante el conflicto. A través de las divagaciones freudianas sobre "melancolía" y "paso al acto", este ensayo explica cómo el comportamiento de Nélida alrededor de la fosa clandestina se convierte en un performance político que exige justicia para los culpables y que busca generar y perpetuar la memoria de las víctimas.

Uncertainty is one of the feelings most commonly associated with the armed struggle between the Peruvian government and the terrorists of the Shining Path during the I980s and I990s. Although such uncertainty takes many forms in the Peruvian imaginary related to the struggle, it predominates in any consideration of the fate of the conflict's many disappeared. As in other Latin American countries which suffered dictatorships or other armed clashes within their borders, Peru's political violence produced a significant number of victims of arbitrary detention and subsequent disappearance. ${ }^{\mathrm{I}}$ Although motivations and tactics differ according to the individual country, two important questions arise from the uncertainty produced by these practices: What happened to the disappeared? And, are they dead? Given the brutality of the conflict, the answer here to the second question unfortunately tends to be affirmative. The likelihood that many of the disappeared are dead, therefore, posits another question, a question that establishes the parameters for an analysis of the violence and the political implications thereof, namely: Where are the remains of these disappeared? 
In the case of Peru, this question is difficult to answer. The combatants involved in the conflict rarely kept records of who their victims were. ${ }^{2}$ Nonetheless, at least some answers may be found in the clandestine mass graves where many of the disappeared were buried. Since the establishment of the Peruvian Truth and Reconciliation Commission (TRC) in 200I, a number of these burial sites have been opened and some remains exhumed. Most of these graves contain the remains of victims who were detained and later killed by the Peruvian police and armed forces. This does not mean, however, that the terrorists of the Shining Path were responsible for fewer fatal victims than the Peruvian state. ${ }^{3}$ Instead, it indicates that the techniques between the two combatant groups were different. If the terrorists brutally paraded the bloody corpses of their victims to install fear in the civilian population of the communities they attacked, the Peruvian government forces buried bodies in an effort to conceal the evidence of their abuse.

Due to the work of the TRC and to the fact that these mass graves are the most immediate and contemporary reminder of the political violence, it is not surprising that the cultural production associated with the conflict has repeatedly represented these mass graves as the stage on which characters who represent the relatives of the disappeared engage in political performances. ${ }^{4}$ In Santiago Roncagliolo's novel Abril rojo (2006), Nélida, the mother of a disappeared, goes to a mass grave and tries to search among the dead bodies for her son. She does this despite physical restraint and intimidation. Considering the fact that the ones who prevent her from searching the mass grave are Peruvian soldiers, and that Edwin, Nélida's son, was detained by the armed forces, her behaviour represents an undeniable act of protest against both the Peruvian government forces who took her son as well as the powerful segments of Peruvian society who seek to persuade the State to set in motion political tactics to divert attention from the conflict and its repercussions. By screaming, crying, and fighting, in performing her sorrow, Nélida makes her past and present grievances with the Peruvian government public. Her sorrow goes, however, beyond simple grief. Nélida cannot and, most importantly, does not want to stop grieving for Edwin's disappearance. She does not know if her child is dead or alive and is aware that her search for answers will, most likely, lead her nowhere. Despite being aware of the very slim possibility of finding answers about Edwin, she searches for his body and continues mourning him endlessly, exemplifying a condition that Freud called "melancholia."

An illness defined as the pathological state of grief created by the loss of a love-object ("Mourning" 53), melancholia becomes the normative 
pattern of behavior for Nélida in Abril rojo. According to Freud, losing a love-object (be it a person, an idea, an actual object) causes grief in the individual, a grief that can be overcome once another love-object takes the place of the original lost object (53). While grief is a completely natural occurrence, Freud stipulates that sometimes an individual cannot stop grieving the loss of the original love-object. It is in these situations, when mourning becomes pathological, that it is called melancholia. Nélida's actions in the mass grave are fueled by the intense and endless grief that her son's disappearance has produced. Her screaming, crying, and searching are, thus, part of her performance of melancholia and also serve as confirmation of her commitment to uncover her son's fate.

Nélida's political performances are strong within the text of Abril rojo despite the fact that she is not the main character in the narrative. The novel's protagonist is, in fact, Félix Chacaltana, a timid district attorney who shields his cowardice and insecurities in his unquestioning and utterly laughable attachment to the law and to the rules of institutional behaviour associated with his profession. The plot in Abril rojo takes place in the year 2000 and revolves around Chacaltana's investigations of several murders committed during the yearly Easter celebrations in the southern Peruvian town of Ayacucho. ${ }^{5}$ At first, the killings do not seem to be connected but, little by little, Chacaltana discovers that all the victims crossed paths during the years of the struggle. Among them are a lieutenant of the Peruvian army who committed abuses during the conflict, a convicted terrorist, a priest who helped the armed forces secretly cremate their victims, the daughter of two Shining Path members, and Justino, a construction worker and also Nélida's son. At the end of the novel, Chacaltana learns that all the victims were killed by Commander Carrión, the military leader in Ayacucho, in order to erase any evidence that might link him to the human rights abuses he committed during the years of the conflict.

The novel provides little detail of the crimes committed by Carrión or Cáceres, the lieutenant who is murdered by the commander, during the conflict. It does mention, however, the name of one victim: Edwin Mayta Carazo. Although Edwin is only present in the novel in references made by the other characters, the reader meets two members of his immediate family: Justino, his brother, and Nélida, his mother. Justino's role in the narrative development of Abril rojo is somewhat stronger than that of his mother (he is, after all, one of Carrión's victims), but Nélida is the character who performs melancholia in the novel.

The possibility of using melancholia to articulate political performances is provided by the intimate connection that exists between 
melancholia and the lost love-object. This connection, as expressed by David Eng and David Kazanjian, "... allows us to gain new perspectives on and new understandings of lost objects" (4). In Abril rojo, this new perspective and understanding of the disappeared implies the rekindling with exponential potency the emotional ties that connected Nélida to her disappeared son. It also allows the maternal character to understand that what happened to her child was a crime that must be prosecuted and punished and was not just the result of unfortunate circumstances. This knowledge provides Nélida with the necessary tools to protest the brutality of the conflict and the efforts made by certain segments of Peruvian society to forget the country's recent violent past.

This struggle to maintain the memory of the disappeared alive, and to keep searching for answers about their fate, may also have their place in psychoanalysis if one recognizes that the obstinate political actions of the maternal character in Abril rojo are instances of psychoanalytic resistance. By dedicating herself completely to the search of her son, Nélida confirms that she is not willing to separate herself from the melancholia that afflicts her. She resists the idea of leaving things as they are. This resistance is embodied in the screaming and crying that she performs at the burial site she visits, that is, in her political performances. As in other pathological conditions treated and studied by Freud, in melancholia resistance manifests itself through "acting out," a behavioural particularity loosely defined by the Viennese clinician in "Remembering, Repeating and Working-Through" as the continuous repetition of actions or attitudes intimately connected to the repressed (150).

Nélida actively represses the possibility of forgetting what happened to her child. She has repressed the idea of a world where his disappearance is forgotten and where she stops behaving in a way that is consistent with her commitment to find out what happened to her son. Nélida's constant presence around the mass graves and her incessant screaming and crying is how she, then, "acts out" her resistance, her attachment both to her melancholia and to her political opinions. What is peculiar about this condition, however, is that Nélida is not afraid of her suffering. She is, in fact, totally committed to it. She is certainly not happy to be grieving indefinitely, but she is more than willing to act out her melancholia to promote awareness of the abuses committed during the conflict and, furthermore, to show how committed she is to her disappeared child and to finding out what happened to him in the only manner of political communication available to her. Her actions underscore the performative nature of trauma; as Diana Taylor explains: 
"[b]efore it can be talked about, trauma manifests itself as an acting out in both the individual and the social body" (1675).

Nélida chooses to act out her trauma at a mass grave, a stage of significance in post-conflict Peru. Abril rojo's narrator introduces the image of the mass grave when Chacaltana is awakened by a group of soldiers who take him by force. The district attorney complies and gets into a jeep. After a few minutes drive and attacked by an overwhelming sense of anxiety, Chacaltana is able to see "[u]n enorme agujero de diez metros de diámetro oculto por los cerros ... [y] [u]n cordón militar alrededor de la ancha fosa" (I63). Despite the fact that nobody provides him with any explanation regarding what rests inside this immense hole, Chacaltana "[s]upo sin necesidad de preguntarlo qué había adentro" (I63).

The description that Abril rojo offers of the mass grave is terrifying. It starts by explaining that, at the beginning, Chacaltana thought that only "cajas viejas y destruidas" were inside the big hole in the ground. After a while, however, he realizes that what he is seeing are "... miembros, brazos, piernas, algunos semipulverizados por el tiempo de enterramiento y otros con los huesos claramente perfilados y rodeados de tela y cartón, cabezas negras y terrosas una sobre otra, formando un montón de desperdicios humanos de varios metros de profundidad" (I64). The crude description of the gravesite demonstrates that the human remains it contains did not receive proper burial. The military personnel guarding the grave further suggest a connection between these bodies and the armed conflict between the Shining Path and the Peruvian government forces. That the mass grave contains victims of the Peruvian armed forces is confirmed when Carrión explains to Chacaltana that what lies inside are the remains of a war, because in Ayacucho "... no hubo un grupo terrorista o dos. Aquí hubo una guerra ... Y en la guerra, la gente se muere" (172). Carrión's decision to use the mass grave as an illustration of the cruelty of the war against the Shining Path implies that the bodies therein belonged to people who were suspected of being part of the terrorist organization and who, because of this, were killed by the Peruvian armed forces. Carrión's simplistic explanation seeks, but fails, to validate the abuses he and his men committed. However, his insistence in bringing Chacaltana to the gravesite also brings to light some of the personality traits commonly displayed by characters representative of the armed forces in the Peruvian cultural production associated with the struggle. In Abril rojo, Carrión's attitude exemplifies the portrayal of institutional power and authority as arbitrary and corrupt, as proposed by Prendes Guardiola, and also illustrates the "... uniforme crueldad del militar, que propaga el miedo y al mismo tiempo lo padece, que odia a los terroristas ..." (235). ${ }^{6}$ 
Chacaltana is not completely persuaded by the Commander's explanation of why there were so many bodies in the mass grave. His unwillingness to accept Carrión's words as the truth comes from what Chacaltana sees at the mass grave, something that is not the dead bodies but that is near them and that blends in with the crude landscape of the makeshift burial place. This "something" is "... una campesina [que] bajaba por la ladera de uno de los cerros del otro lado [de la fosa]. Tropezaba y rodaba hacia las faldas pero se incorporaba para seguir su camino ... grita[ndo] algo en quechua" (165). The Quechua-speaking woman is none other than "... la madre de Justino y Edwin, la señora [Nélida] Carazo de Mayta" (I65).

The choice that Nélida makes to act out her melancholia by showing up in such a dangerous place as the mass grave implies that she is willing to subject herself to the continuous and endless mourning that this condition produces. Freud explains that mourning or "... grief involves grave departures from the normal attitude to life..." but that it should not be considered "... a morbid condition [because] after a lapse of time it will be overcome ..." ("Mourning" 153). Here, given that the publication date of Abril rojo is 2006 and that there is no mention of what actually happened to Edwin, I wish to define Nélida's melancholia as a "chronic mourning" instead of the Freudian characterization as "pathological mourning." The adjective "chronic" is applied here to identify and describe the continuity and the recurrence of the grief that the disappearance of Nélida's son produces. Since it is not indicated in the novel that Edwin's body is ever found, his mother's mourning has no apparent end and she is, thus, unable to overcome it.

A theoretical question arises from this change in nomenclature: since Freud does not establish a definitive period after which mourning will be overcome, is it possible that, some day in the future, Nélida will end her mourning? Considering, once again, that there is no indication in the narrative that she ever finds the remains of her son, the best answer would be no. This answer reinforces the hypothesis that the maternal character in Abril rojo is involved in an endless and incomplete process of mourning. It may also be read, however, as a critical articulation of what is taking place in Peru as of 20I4. Isaías Rojas-Pérez chronicles the excavations of one of the most infamous mass graves investigated by the TRC, that at the military base Los Cabitos in Ayacucho. The findings of the forensic team in charge of the exhumation allowed the scientist to theorize that 
... the military had sacked the clandestine mass graves containing the bodies of its victims in order to burn them in ad hoc blast furnaces. The ashes and remains of those burned bodies were subsequently disposed of in a garbage dump in the surrounding area. Subsequently, the military demolished the furnaces and dumped the debris in the same garbage dump. (I54)

If this hypothesis is correct, and - according to Rojas-Pérez - there is considerable evidence to support it, the bodies found in the mass grave at Los Cabitos suffered terrible and undignified treatment. Once the victims were killed, their bodies were buried first and later they were exhumed, burnt, and thrown away. Due to this mistreatment, "... the usual techniques of identification - such as postmortem data and/or exposition of the victim's recovered clothes and remains before their potential relatives did not render positive outcomes" (154-155). Furthermore, "... the individualization and identification of the charred fragments and ashes of human bones proved to be an impossible task" (155). ${ }^{7}$

Abril rojo suggests that the remains of the fictitious disappeared have suffered similar patterns of destruction to those of the bodies of the real disappeared as described by Rojas-Pérez. The destruction of evidence guarantees that Nélida's mourning will be constant and recurring - or chronic. Her incessant cries, questions and accusations should thus be considered as performances of chronic mourning because, regardless of the time spent between her loss and the events at the mass grave, she will always be grieving the disappearance of her child.

Rojas-Pérez's article also focuses on the behaviour of the women that Nélida represents and who attended excavations such as the one he profiles. One of his main anthropological conclusions is that by searching for answers and by overseeing the exhumation of the remains found in mass graves, these women are engaged in acts of mourning. This mourning, he argues, "[does] not lead to closure but to ... the ongoing struggle against state terror" (153). Although I disagree with the characterization that Rojas-Pérez ascribes to some of the practices of the post-conflict Peruvian government as "state terror," I agree with the hypothesis that the families of the disappeared, through performances of chronic mourning, enter into the political dimension of the national discussion about the conflict and its sequels in Peruvian society. ${ }^{8}$ This work, of course, is not anthropological since I propose to analyse and identify these practices in an entirely fictional cultural product. Nevertheless, it is impossible not to see that similarities between Nélida and the women profiled in Rojas-Pérez's article do exist. In reality and fiction, the mothers of the disappeared display an insatiable hunger for 
truth. Furthermore, Abril rojo's fictional character and real-life individuals also ask questions and are rarely satisfied with the answers they receive. Unlike the study of the real mothers of the disappeared, Roncagliolo's text delves into the emotional motivations that make Nélida articulate instances of political speech through the performance of her melancholia. The character is involved in political behaviours that reflect upon the dissatisfaction that arises from the insufficient, and still controversial, efforts of individuals and organizations to uncover the truth regarding the fate of the disappeared in post-conflict Peru, even if she is not motivated by a openly stated particular political organization or ideology. Nélida articulates her sentiments of dissatisfaction and outrage because she has been affected emotionally by the abuses committed by people who were invested with political power during the conflict. These abuses affect Nélida deeply, so deeply that she feels the need to perform or act out her melancholia to make a political point.

The psychological motivation for Nélida's political performance at the gravesite is explained in the report that Chacaltana writes about Edwin's arrest. This document outlines every event of Edwin's detention and interrogation in 1990 . What is particularly striking about the report is that although it reads like any other legal document, some of its contents is extremely cruel and painfully graphic. When describing how the Peruvian Army unit led by Lieutenant Alfredo Cáceres Salazar entered the Mayta Carazo house, for example, Chacaltana's report does not soften the truth in order to make the house invasion less brutal and, instead, establishes that the soldiers:

... irrumpi[eron] en la citada vivienda sin aviso previo y haciendo uso de su prerrogativa, encapuchados y armados con sendos fusiles $\mathrm{H} \& \mathrm{~K}$ de combate antisubversivo, encontrando en su interior a la familia compuesta por el susodicho sospechoso, su hermano Justino y la madre de ambos, señora Nélida Carazo viuda de Mayta, que pernoctaban en el lugar. (133)

This description is by no means the cruelest episode in the report. Throughout Edwin denies any kind of involvement with the Shining Path but Cáceres is not convinced by these denials and, instead, takes them as confirmations of Edwin's participation in terrorist activities because "... los terroristas se caracterizan por negar siempre su participación en los hechos" (I35). Chacaltana's report mentions that, due to this paranoia, the soldier practices certain interrogation techniques on the suspect. One of these consists of “... atar sus manos a la espalda y dejarlo colgar suspendido del techo por las muñecas, hasta que el dolor le permita 
proceder a confesar sus actos delictivos" (I35). Another one is known as the "submarino" and consists of "... sumerg[ir] la cabeza del sospechoso en una batea de agua varias veces hasta aproximarlo a la asfixia, de modo que su receptividad a las preguntas de las autoridades aumenta significativamente" (135).

The report indicates that despite the brutality of these techniques, Edwin keeps denying his involvement in the terrorist activities of the Shining Path. As a result, Cáceres has no other option but to let him go the next day. Since the report that Chacaltana writes is based on official documents, it points out that Edwin's liberation was noted in the "... actas del día de la base military de Vischongo" (135). It is not clear, however, if Edwin was really freed or if the official documents were doctored to show a release that, in reality, did not take place. This lack of clarity is accentuated when the report states that "Edwin Mayta Carazo se encuentra desde ese día en paradero desconocido [y] [s] u familia niega haberlo visto de nuevo, del mismo modo que sus amigos y conocidos ..." (I35). Consequent on the institutional tone here the idea that Edwin might have been disappeared is nowhere entertained in the report, and instead there is speculation that since nobody has heard from him in the last ten years this reinforces "... la tesis de que ha pasado a la clandestinidad como miembro de algún grupo terrorista, probablemente Sendero Luminoso, aun después del fin del terrorismo, hasta la fecha actual de abril del 2000" $(135-36)$.

The euphemistic language of the report loses its discursive potency once Nélida appears near the mass grave guarded by the soldiers. By simply appearing near the excavation site, she establishes an alternative version of Edwin's fate, a version that not only discredits the contents of Chacaltana's report but also proposes a far more violent and tragic sequence of events connected to his detention and disappearance. Due to the rebellious stance that her presence among the soldiers at the gravesite implies, Nélida is acting out her dissatisfaction with the government and, thus, is articulating a form of political speech by performing her melancholia in front of Chacaltana, Carrión, and his men. Although the report is correct in saying that Edwin has not been seen since his alleged release from the army base of Vischongo, the possibility that he might have gone underground and deliberately cut communications with his family and friends seems most unlikely, especially since his mother is still looking for him inside mass graves. The unlikelyhood that Edwin is even still alive is also strengthened by the description that Hernán Durango González, an imprisoned terrorist who allegedly knew Edwin, gives to Lieutenant Cáceres, the army officer who commanded the seizure of the suspect. In an 
interview conducted by Chacaltana as part of his investigation, Durango tells the district attorney that Edwin was taken by "... el Perro Cáceres" (I46-47), adding that the same "Cáceres no liberaba sospechosos. Se deshacía de ellos" (I47).

Chacaltana is not convinced by Durango's accusation and keeps trying to piece together events from the past that might be of importance in his investigations. While searching the archives of the district attorney's office, Chacaltana discovers that Nélida made a formal complaint about the disappearance of her son after he was taken by the army unit headed by Cáceres. He also finds that this complaint was withdrawn the day after it was made but without the plaintiff's signature (139). This evidence, plus Nélida's appearance at the gravesite, demonstrates that she is still searching for the truth about what really happened to Edwin.

An important question arises at this juncture: Who might know what actually happened to Edwin? In Abril rojo this knowledge is attributed to the most powerful person in Ayacucho: Commander Carrión. This becomes evident when the officer answers Chacaltana's request to meet face to face with Cáceres and Edwin to clarify their involvement in the series of murders that he is investigating. Carrión answers that Chacaltana already "[c]onoció a Edwin Mayta Carazo, al menos a una parte de él, [esa] mañana mientras se asomana a la fosa ..." (177). The revelation surprises Chacaltana and also tells him that Carrión knows a lot more than he is saying. This information is important for Chacaltana's investigation because, as is revealed near the end of the novel, Carrión is responsible for all the murders that the district attorney is trying to clarify. All four of the victims were involved in one way or another with Carrión's activities as an army captain in Ayacucho during the conflict and every one of them had first-hand knowledge of the abuses he committed.

Since Nélida's melancholia was produced directly by Carrión's actions and given that the commander is a figure of the Peruvian government, she may thus be considered a metonymic representation of the years of encapsulated mourning that many Peruvians endured because of human rights abuses committed during the conflict. Beyond the clear suggestion that there is an historical need to investigate and prosecute these abuses, Abril rojo also proposes that they have both national and personal implications. On the one hand, there is a need for the entire Peruvian population to remember and understand what really happened in Ayacucho and other parts of the country during the violent period of the I 980 s and I990s in order to guarantee that similar violence never happen again. On the other hand, finding answers about these human rights abuses might also allow individuals and families to come to terms with 
their loss. It is relevant to remember here that many Peruvians are in a state of melancholia because their loved ones were disappeared during the conflict and there has been no official information about their fate. These Peruvians are looking for answers and are willing and able to ask the questions needed to uncover the truth. Nélida, without a doubt, represents these individuals and also the melancholia that affects them.

How Nélida's melancholia connects with her behaviour may be explained when one considers that a few years after Freud initially conceptualized melancholia, he revisited the definition and added an important feature to the condition: a "... sense of guilt, which is finding its satisfaction in the illness and refuses to give up the punishment of suffering" (Ego 68). This sense of guilt is born from the individual's set of moral standards or superego and also by the process of identification that the said individual experiences with the lost love-object. The individual affected by melancholia identifies him or herself with the lost love-object and this identification is so "over-strongly conscious" that said individual accepts this guilt and "submits to the punishment" even though he or she is not actually guilty of any wrongdoing $(70) .{ }^{9}$

Nélida seems to suffer from this sense of guilt. In Freudian terms, such guilt is born from her superego, from that moral/maternal condition that originates from knowing that her efforts are not sufficient to find her son. Melancholia, however, has an additional dimension in the case of the maternal character featured in Abril rojo. ${ }^{10}$ Besides being an expression of the strong emotional connection associated with motherhood, this character's melancholia may also be a performative vehicle to articulate political statements and views. By unceasingly searching in the dirt, screaming, and crying around the mass grave, Nélida successfully "acts out" her political statements of disgust and indignation towards the violent conflict that put her loved one inside one of these terrible holes in the ground.

Nélida's actions around the gravesite are clear indications of this performance of melancholia and its implicit political commentary. This is evident because the woman is not peacefully regarding a gravesite but is actively trying to get closer into the hole in the ground. As she draws near the edge of the grave, the narrator recounts the following sequence of events:

Los soldados la tomaron del brazo, pero ella se soltó y continuó corriendo y gritando... Parecía querer arrojarse al interior. Uno de los soldados le jalaba la pollera. Otro forcejeaba con ella, tratando de alejarla a rastras. La mujer se negaba a moverse. Parecía más fuerte que los otros tres juntos. El tercer soldado sacó una 
pistola. Ella no la vio. Estaba de espaldas, concentrada en la fosa y en sus gritos. El soldado levantó el arma hacia su espalda. (165-66)

Nélida is looking for her son in the grave. Her melancholia is forcing her to go closer to the hole to see what rests inside the grave. Even if the likelihood of finding Edwin inside the hole is minimal, she still has the physical need to see if his body is inside the tomb. What is striking about this episode is Nélida's defiant attitude. She does not seem to be afraid of the soldiers who guard the site. In fact, she yells at them. This attitude shows the strong commitment that she has to finding the truth about her son's fate. She is unwilling to forget Edwin and wants and needs to know if he was killed and, if so, the circumstances of his demise. The physical and verbal struggle in which Nélida engages is thus not just an visceral demonstration of feeling. It is a political performance. She struggles against three armed soldiers. When one of these soldiers points a gun at her she is unfazed and keeps screaming. She does not care if she dies. She is only interested in knowing if her son is inside that mass grave.

Nélida's disregard for her own life is a performance of her melancholia because, as Freud points out, melancholiacs tend to feel "... profoundly painful dejection, abrogation of interest in the outside world, loss of the capacity to love, inhibition of any activity and a lowering of the selfregarding feelings to a degree that finds utterance in self-reproaches and self-revilings, and culminates in a delusional expectation of punishment" ("Mourning" 153). Even though Abril rojo suggests that her actual loss took place ten years prior to the discovery of the hidden gravesite, Nélida's pain seems to be as strong as it was when Edwin was captured by Cáceres and his men. As represented in the novel, the Nélida of the year 2000 is still distraught about what happened in 1990. She has not replaced Edwin with another love-object. It is known that she has another son named Justino but, through her incredibly forceful performance at the site of the mass grave, she shows that she is still interested in knowing what happened to Edwin. She still longs for him and mourns his disappearance.

But how does Nélida's melancholia become political performance? Eng and Kazanjian's theoretical approach to melancholia helps explain this transformation. By proposing that melancholia has a "... continued and open relation to the past [that] finally allows us to gain new perspectives on and new understandings of lost objects" (4), they indicate the social and political potency of the condition in the social environments in which the melancholiac resides. ${ }^{\text {II }}$ By getting involved in physical altercations with the soldiers who guard the mass grave, Nélida demonstrates that she has developed a "new understanding" of Edwin not only as her son but also as 
a victim. This, in turn, has allowed her to create and internalize a new perspective on the government that was supposed to protect its citizens but instead inflicted pain on them. Given this new perspective on military abuse of Peruvian citizens, Nélida decides to continue looking for her son not only because she wants to know what happened to him but also because she wants to show the brutality of a governmental structure that did not do what it was supposed to do. This is particularly striking because a decade has passed since she saw her son for the last time but she still thinks of him and is still willing to do whatever it takes to figure out what happened to him.

Nélida's performance echoes Diana Taylor's ideas regarding performance, trauma, and memory. Discussing some of the most visible social movements against the dictatorship in Argentina, Taylor explains that "... trauma-driven performances offer victims, survivors, and human rights activists ways to address the society-wide repercussions of violent politics and also, indirectly to relieve personal pain" (I674). Nélida, then, by publicly performing her pain in front of the soldiers, informs Peruvian and international audiences of the repercussions of the conflict. But unlike the street protests studied by Taylor in Argentina, Nélida's performance does not address her personal pain indirectly. How she embodies her pain is the performance itself. She expresses her social and political dissatisfactions by grieving and by showing that she is not willing to forget her son.

The continuity of this grief proves that Nélida, even a decade after the loss of her son, still resists "working through" her melancholia. Her performance at the mass grave guarded by Carrión's men leaves no doubt that she has, in fact, adopted her resistance as the instrument with which to articulate political speech. Her screams and cries at the gravesite are, therefore, how she "acts out" her melancholia. This erratic behavior should not be considered simply as a symptom of her chronic mourning but also as her own personal way of expressing her opinion about what happened to her son specifically and to the country in general during the years of the violence. By acting out her unfinished grieving process through screams and cries, Nélida sends a clear statement to the segments of the Peruvian population who were not and are not interested in taking the necessary actions to stop the conflict. Furthermore, she blames this group of Peruvians for her incessant and never-ending mourning.

Although Nélida's thoughts about her son are not explicitly outlined in the narrative of Abril rojo, the novel implies that Edwin was, in fact, involved in terrorist activities and that he was a member of the Shining Path. The novel does not delve into a debate about the character's culpability or criminality, it only reports the fact that Edwin was captured 
by Cáceres and his men and never returned to his family. This lack of focus on culpability is not accidental; rather, it should be understood as a comment about the process of reconciliation outlined by the TRC which Rojas-Pérez summarizes as follows: "... the Peruvian TRC understood reconciliation as the need for the state to 'reconcile' with its citizens by (re)granting rights and legal protections that historically have been denied" (15I). Although optimistic and positive, this definition of reconciliation only outlines changes for the future. As such, it leaves out any possible redress of the human rights abuses committed in the past. Rojas-Pérez omits such possibility from his definition of reconciliation because it reflects an important particularity of how the process has been understood by the Peruvian ruling class even after Alberto Fujimori's political demise in 2000: reconciliation means to move on and to forget the tragic nature of the conflict. In psychoanalytic terms, reconciliation would be analogous to "working through." Since Nélida has made it clear that she is not interested in this possibility and that, instead, she is eager to "act out" her grief, Abril rojo does not comply with the project of reconciliation outlined by Rojas-Pérez. The text does subscribe to the idea of a government that functions according to the rule of law in which all citizens have the same legal rights and protections and also rejects the possibility of leaving things be. Nélida will not forget her son and the country should not forget the many victims of the conflict.

Nélida's behaviour at the mass grave is, in a way, a response to Carrión's cruelty and fear. While fighting to have the opportunity to dig through the dirt of the mass grave, Nélida embodies a different kind of emotional reaction towards the violence. While Carrión seeks to convince Chacaltana that the remains inside the mass grave belong to enemies, Nélida's attitude indicates that the corpses inside the horrendous hole on the ground belong to human beings who were illegally executed and buried without any trace of dignity. She does not make any judgment about the potential guilt of the people buried in the mass graves. In her performance, such determinations are unnecessary because she proposes that everybody's remains, regardless of who they were or what they did, deserve to be laid to rest with respect. Furthermore, Nélida's actions also indicate that, in contrast to Carrión's assessment of the conflict, the bodies inside the mass grave did not belong to enemies but to someone's father, mother or child, like her own.

The national debate about what reconciliation is or should be in terms of the armed conflict and its consequences has given way to the creation of a number of public and private institutions and organizations whose mission is or was to find meaningful ways to deal with the emotional and 
political wounds left by the violence. Although many of the people represented by Nélida form part of these institutions, she does not associate with these organizations. She is alone in her quest and she does not have any other support than her determination. ${ }^{\text {I2 }}$

Beyond her independence, Nélida possesses a galvanized sense of motherhood. The emotional connection she has to her disappeared son is what drives her to act. This is a common feature of other groups seeking answers regarding the disappeared. Marguerite Guzman Bouvard proposes that the Madres de la Plaza de Mayo, a group of women who protest their children's disappearances by the Argentine dictatorships in the I970s and I980s, "... sought to transform the political system to reflect the definition of maternal values as concern for the well-being of all children ..." and that "[t]hey provide us with an alternative model of political action based upon familial and community responsibility rather than upon individual goals" (15). Although Nélida is not involved in an organization like the one profiled by Guzman Bouvard, her quest for Edwin does put motherhood in a preferential political space.

This placement of motherhood establishes a particular connection between loss, emotions, and politics. Nélida is plagued by unresolved grief. Beyond the biological connection between her and her lost love-object, there is also a powerful emotional tie between mother and son that is broken when Edwin is taken away. The breaking of this link might cause, under any circumstances, a potent disruption in the psychic and psychological continuity of a person, but in the case of Nélida, this disruption is exacerbated by another powerful emotion: uncertainty. She never understood why her son was detained. This uncertainty grew as the woman sought for answers about Edwin in the days, months, and years after his detention. She neither knew where her son was held or if she would see him again. What she does know and has known all along, however, is that her child is no longer with her and that the emotional relationship she used to have with her son has been disrupted by his detention and subsequent disappearance.

While the TRC and civil society-sponsored efforts to attain reconciliation must receive the bulk of the credit for retrospectively analysing the conflict and its violence, the extensive and emotional labour of the family members represented by Nélida also constitutes a valid element of the struggle against oblivion currently fought in the intellectual and political spheres of the country. Abril rojo contributes to this struggle because, as Victor Vich points out, "... la novela ha sido escrita para revelar aquello que el discurso oficial ha intentado reprimir..." and also because the work "... interviene en el debate político proponiendo 
representaciones que no por su carácter de ficción dejan de ser altamente significativas respecto a la pugna de intepretaciones sobre lo sucedido" (248). Nélida's behaviour is one of these representations because it protests against and counteracts the temptation of dealing with the recent violent past of the country by forgetting it altogether. Her suffering and courage fuel the on-going political struggle between those who advocate dealing with the consequences of the conflict through forgetting and those who seek to work through those consequences by remembering and critiquing the actions, reactions, and abuses committed during the i98os and 1990 s.

By actively performing her melancholia, Nélida announces that there is no easy way out of the national discussion concerning Peru's complex recent past. It is not possible to "work through" the melancholia left by the conflict; it simply cannot be done. Although some might like to forget this trauma and shift their attention to another national preoccupation, there is still an important segment of the country that wants to remember what took place during the struggle and, through this process of remembering, build a Peruvian society where social schisms may be resolved without violence and through dialogue and true reconciliation.

Elon University

NOTES

I Obvious examples include Argentina, Chile, Colombia, and Guatemala.

2 The Peruvian Truth and Reconciliation Commision includes the number of disappeared in the figure of fatal victims produced by the conflict. This number is 69,280 (Comisión, Informe App.2:13).

3 The Shining Path, in fact, is responsible for $54 \%$ of total number of victims reported to the TRC (Comisión, Hatun I8-ı9).

4 Mass graves also appear in numerous cultural works such as the films La boca del lobo (1989) and Ojos que no ven (2003) by Francisco Lombardi, the novella Adiós Ayacucho (1986) by Julio Ortega, the theatrical adaptation of Ortega's work also titled Adiós Ayacucho (1990) by the theater troop Yuyachkani, and Alonso Cueto's novel La hora azul (2005). They also appear in the short story collections Infiernillo (2004) by Emilio Laynes Luján, Cuentos al resplandor del candil (1995) by Aquiles Pacheco Fasce, and Réquiem (1987) by Feliciano Padilla Chaico (Cox 255). Mass graves are also present in several works of poetry, and plastic and performance arts associated to the conflict. 
5 Ayacucho is famous for its Catholic piety. It has 33 Catholic churches and its Easter celebrations last for several weeks. Ayacucho was the hardest hit part of the country during the armed struggle and, due to the violence, the traditional Easter celebrations suffered extensive cutbacks. Since the fall of the Shining Path in the I990s, however, Easter has regained relevance in Ayacucho and it has become one of the most popular tourist attractions celebrated in the town.

6 Prendes Guardiola groups Abril rojo with Óscar Colchado Lucio's 1997 novel Rosa Cuchillo and with Alonso Cueto's La hora azul (2005). He argues that, in these three novels, characters that look for a "disappeared" are also searching for their personal truths and circumstances (229).

7 Rojas-Pérez admits that DNA testing was not “... yet available as of this writing [2013]" (155). Considering that the national discussion about conflict is losing the relevance it had during the years of the TRC, it is unlikely that DNA testing will ever be performed on the remains found at Los Cabitos.

8 Rojas-Pérez considers that "state terror" is still practiced in Peru. He arrives at that conclusion arguing that, "[o]fficial denial of the existence of prisoners, torture, disappearances, or even of internal warfare itself wages terror because it undergirds the arbitrariness of the exception" (157). The main problem with this characterization is that Rojas-Pérez seems to group all the state organizations under one single banner. This ignores the fact that there are organizations of the Peruvian state that are still working to find answers regarding the human right abuses committed during the conflict. Two of these organizations are the Defensoría del Pueblo and the Ministry of Culture that, in cooperation, curate and exhibit a version of the photographic exhibit about the conflict titled Yuyanapaq. Para recordar on the sixth floor of the Ministry's headquarters.

9 Tammy Clewell reports that "Freud's mourning theory has been criticized for assuming a model of subjectivity based on a strongly bounded form of individuation" (43). Kathleen Woodward, one of the most prominent critics of Freud's theory of mourning, proposes the existence of a status between mourning and melancholia where one still mourns but is not devoted to mourning (96).

IO Nélida is not the only maternal character in Abril rojo. Chacaltana's mother is also featured in the novel. Her presence is only symbolic since she has been dead for several years before the beginning of the work's narrative action. Chacaltana behaves, however, as if his mother were still alive and talks to her constantly. The psychoanalytic implications of this behaviour go beyond the scope of this article.

II The academic discussion of the relationships between performance, trauma, and performance is vast and encompasses several disciplines and approaches. 
A useful resource to understand this conversation's development is the volume Visions and Revisions: Performance, Memory, Trauma edited by Bryoni Trezise and Caroline Wake. The essays featured in the book, as explained by the editors in their "Introduction," take an approach based on a "... reversed and reciprocal gaze - performance studies as a lens for trauma, trauma as a lens for performance - ... [that allows] these two fields [to] both 'envision' and 'revision' one another" (13). Echoing Joseph Roach's and Diana Taylor's respective works on performance, Trezise and Wake argue that "... writing about performing memory and trauma is a process of writing at the intersection of two prefixes, the 're' [from repetition] and the 'un' [from unspeakable][,] where one can simultaneously mourn the loss of events, history and disciplinarity and nonetheless celebrate their endless repetition(s) in contemporary research in the humanities" (I4). Besides analyzing the phenomenology of performance through trauma and memory, Trezise and Wake also problematize the performers' role in society by establishing that "While grief is internally felt, its outward performance at points of crisis or loss also functions according to particular conventions that determine the future role of the mourner within social life" (2I).

I2 Regardless of why Nélida decides to look for Edwin independently, it is important to note that, as in many other countries in Latin America, the search for the disappeared in Peru has shifted from an independent endeavour to a collective one. Under the sponsorship of the TRC, organizations such as the Asociación Nacional de Familiares de Secuestrados, Detenidos y Desaparecidos del Perú (ANFASEP) were able to ascertain some amount of recognition and identification. As the Madres de la Plaza de Mayo in Argentina or the Agrupación de Familiares Detenidos Desaparecidos in Chile, ANFASEP is made up of relatives of people who were detained and never returned to their families. Their main objective is to keep asking about the fate of their loved ones and to keep their memory alive (Tamayo I3I).

\section{WORKS CITED}

Bouvard, Marguerite GuZman. Revolutionizing Motherhood: The Mothers of the Plaza de Mayo. Wilmington: Scholarly Resources Inc., I994.

Clewell, tammy. "Mourning Beyond Melancholia: Freud's Psychoanalysis of

Loss." Journal of the American Psychoanalytic Association 52.I (2004): 43-67.

COX, MAR K R. "Bibliografía anotada de la ficción narrativa peruana sobre la Guerra interna de los años ochenta y noventa (con un estudio previo)." Revista de Crítica Literaria Latinoamericana 34.68 (2008): 227-268. 
ENG, DAVID L. AND DAVID KAZANJiAn. "Introduction: Mourning Remains." Loss: The Politics of Mourning. Eds. David L. Eng and David Kazanjian. Berkeley: U of California $\mathrm{P}, 2003$. $\mathrm{I}^{-25}$.

FREUD, SI G MUND. "Mourning and Melancholia." Collected Papers. Trans. Joan Riviere. Vol. 4. London: Hogarth Press and the Institute of Psycho-Analysis, I934. $152^{-1}$ I7O.

—. "Remembering, Repeating and Working-Through (Further Recommendations on the Technique of Psycho-Analysis II)." The Standard Edition of the Complete Psychological Works of Sigmund Freud. Trans. James Strachey. Vol. 12. London: Hogarth Press and the Institute of Psycho-Analysis, I958. I45-156.

-. The Ego and The Id. Trans. James Strachey. New York: W.W. Norton and Company, i96r.

PERÚ. COMISIÓN DE LA VERDAD Y RECONCILIACIÓn. Informe Final. Anexo 2. Lima: CVR, 2003. Web.

-. Hatun Willakuy: Versión abreviada del Informe Final de la Comisión de la Verdad y Reconciliación. Lima: CVR, 2004.

PRENDES GUARDIOLA, MANUEL. "Constantes temáticas en tres novelas peruanas sobre la época del terrorismo." Romance Notes 50.2 (2010): 229-239.

Rojas - PÉrez, IS Aí as. "Inhabit Unfinished Pasts: Law, Transitional Justice, and Mourning in Postwar Peru." Humanity: An International Journal of Human Rights, Humanitarianism, and Development 4.I (2013): I49-170. ronCagliolo, santiago. Abril rojo. Mexico City: Alfaguara, 2006. TAMAYo, ANA maRía. "ANFASEP y la lucha por la memoria de sus desaparecidos (1983-2000)." Jamás tan cerca arremetió lo lejos: Memoria y violencia política en el Perú. Ed. Carlos Iván Degregori. Lima: Instituto de Estudios Peruanos and Social Science Research Council, 2003. 95-134.

TAYLOR, DiAnA. "Trauma and Performance: Lessons from Latin America." PMLA I2I.5 (2006): I674-I677.

TREZISE, BRYONI AN D CAROLINE WAKE. "Introduction-From Sight to Site: Performance in Memory and Trauma Studies." Visions and Revisions: Performance, Memory, Trauma. Eds. Bryoni Trezise and Caroline Wake. Copenhagen: Museum Tusculanum Press, 2013. II-28.

VICH, Vict oR. "La novela de la violencia ante las demandas del mercado: la transmutación religiosa de lo político en Abril rojo." Contra el sueño de los justos: la literatura peruana ante la violencia política. Eds. Juan Carlos Ubilluz et al. Lima: IEP, 2009. 247-260.

WOOdWARD, KATHLEen. "Freud and Barthes: Theorizing Mourning, Sustaining Grief." Discourse I3.I (1990-91): 93-ıІо. 